\title{
Catchment-scale vulnerability assessment of groundwater pollution from diffuse sources using the DRASTIC method: a case study
}

\author{
Y. S. Yang ${ }^{1,2} \&$ L. Wang ${ }^{3}$ \\ 1 Jilin University, College of Environment \& Resources, Changchun 130026, China \\ yangy6@cf.ac.uk \\ 2 Cardiff University, School of Earth \& Ocean Sciences, Cardiff CF10 3YE, UK \\ 3 British Geological Survey, Keyworth, Nottingham NG12 5GG, UK
}

Received 14 April 2009; accepted 22 March 2010; open for discussion until ...

Citation Yang, Y. S. \& Wang, L. (2010) Catchment scale vulnerability assessment of groundwater pollution from diffuse sources using the DRASTIC method: a case study. Hydrol. Sci. J. 55(5), xxx-xxx.

\begin{abstract}
The catchment-scale groundwater vulnerability assessment that delineates zones representing different levels of groundwater susceptibility to contaminants from diffuse agricultural sources has become an important element in groundwater pollution prevention for the implementation of the EU Water Framework Directive (WFD). This paper evaluates the DRASTIC method using an ArcGIS platform for assessing groundwater vulnerability in the Upper Bann catchment, Northern Ireland. Groundwater vulnerability maps of both general pollutants and pesticides in the study area were generated by using data on the factors depth to water, net recharge, aquifer media, soil media, topography, impact of vadose zone, and hydraulic conductivity, as defined in DRASTIC. The mountain areas in the study area have "high" (4.5\% of the study area) or "moderate" (25.5\%) vulnerability for general pollutants due to high rainfall, net recharge and soil permeability. However, by considering the diffuse agricultural sources, the mountain areas are actually at low groundwater pollution risk. The results of overlaying the maps of land use and the groundwater vulnerability are closer to the reality. This study shows that the DRASTIC method is helpful for guiding the prevention practices of groundwater pollution at the catchment scale in the UK.
\end{abstract}

Keywords groundwater vulnerability; agricultural diffuse groundwater pollution;

DRASTIC; GIS modelling; EU Water Framework Directive

\author{
French title \\ Resume \\ [Please help out with French translation! Many thanks. ]
}

\section{Mots clefs}

\section{INTRODUCTION}

Groundwater is a very important source of potable freshwater on the Earth and plays a significant role in maintaining life and social development. Groundwater pollution from diffuse sources is not only a serious environmental issue but also an economic and human health problem. For example, nitrate groundwater pollution could cause health problems such as "blue baby syndrome" (USDA, 1991; Matson et al., 1997), and cancer risks (Rademaher et al., 1992; Yang et al. 2007), and high drinking water treatment costs (Pretty et al., 2000).

Once groundwater is contaminated, it is very costly to clean-up and may take a long time to recover. Moreover, spatial variability and data constraints preclude monitoring of all waters and make remediation activities expensive and often impractical (Babiker et al., 2005). 
Therefore, the measures for groundwater pollution prevention before pollution occurs contribute to reducing contaminants in the source water, and are more feasible and effective than remedial measures (Koo \& O’Connell, 2006). In agricultural diffuse groundwater pollution (ADGWP), it is difficult to tell exactly where the pollutants come from. Thus, it is difficult to determine the contribution of diffuse sources to water pollution at the regional scale (Defra, 2002a). ADGWP should be prevented at the catchment or watershed scale. Groundwater vulnerability assessment, which is capable of delineating zones that are more susceptible to pollutants from diffuse agricultural sources at the catchment scale, is important for guiding the prevention activities for ADGWP.

Groundwater vulnerability means the possibility of percolation and diffusion of contaminants from the ground surface into the groundwater system (Vrba \& Zoporozec, 1994; Palmer et al., 1995). Many groundwater vulnerability studies have been carried out worldwide (Gogu et al., 2000; Bekesi \& McConchie, 2002; Daly et al., 2002; Dixon et al., 2002; Gogu et al., 2003; Gemitzi et al., 2006; Yang \& Wang, 2010). To date there are four main types of method for groundwater vulnerability assessment (Worrall \& Besien, 2005; Wang \& Yang, 2008): (a) modelling approaches using physical-process-based simulation models to estimate approximately the contaminant transport (Barbash \& Resek, 1996; Thapinta \& Hudak, 2003); (b) observation-based methods generating groundwater vulnerability maps based on observed contaminants; (c) statistical methods to correlate spatial variables with the actual occurrence of pollutants in groundwater (Babiker et al., 2005); and (d) index methods combining the factors controlling the pollutant transport from the ground surface into the saturated zone and resulting in spatially-distributed vulnerability indices. With index methods, there is a major drawback in the subjectivity in the factor weighting and assignment of numerical values. However, index methods do have the following advantages: (a) information on factors such as rainfall and depth to groundwater may be available over large areas, which makes them suitable for regional scale assessments (Thapinta and Hudak, 2003); and (b) they are easy to understand and apply.

The DRASTIC method, an index method, was developed by the US Environmental Protection Agency (EPA) (Aller et al., 1987). Although DRASTIC is a method using subjective weighting and assignment of numerical values to factors, these factors and their weighting values, which were selected and calculated based on the knowledge and understanding of groundwater pollution by a group of groundwater pollution experts, can well reflect the key mechanisms of the groundwater pollution pathways. Therefore, the DRASTIC method has been widely used for groundwater vulnerability (Worrall \& Kolpin, 2004; Babiker et al., 2005). The effectiveness of DRASTIC has met with mixed success (Rupert, 2001).

Within the UK context, many groundwater pollution potential studies have been carried out at the national or regional scale (Wang \& Yang, 2008). These studies are useful in finding the priority for groundwater pollution protection work, but have limitations in guiding prevention practices for ADGWP at the catchment scale. For example, most of Northern Ireland should be designated as nitrate vulnerable zones (NVZ), according to the new demands of the European Commission (Jordan \& Smith, 2005). This could hardly guide the prevention practices of ADGWP that should be carried out at the catchment scale. In addition, the index methods used in the UK for groundwater vulnerability assessment consider only a few factors (such as overlying soil cover, the presence and nature of the drift, the nature of strata, and the thickness of the unsaturated zone). This could lead to high uncertainty in the result (Palmer et al., 1995; Palmer \& Lewis, 1998; Giupponi \& Vladimirova, 2006). Therefore, it is necessary to find a feasible approach for vulnerability assessment of groundwater pollution at the catchment scale that is useful for the prevention of ADGWP in the water resources management of the Northern Ireland.

This study aims at: (a) evaluating the DRASTIC method for assessing groundwater pollution vulnerability in a catchment dominated by agricultural land use - taking the Upper Bann catchment of Northern Ireland as an example; and (b) overlaying land-use data on groundwater vulnerability maps to represent groundwater pollution risk in the study area. 


\section{STUDY AREA}

The Upper Bann catchment, in Northern Ireland (NI), was used as a case study area in this study (Fig. 1). Northern Ireland is a rural and agricultural province; $66 \%$ of the population lives in Belfast, the second largest city in Ireland. The towns of Craigavon, Lurgan and Portadown combined in the 1960s as part of the UK "New Town" development scheme, to form one large continuous urban sprawl that covers an area of $260 \mathrm{~km}^{2}$ in the Upper Bann catchment, with a population of approximately 80000 inhabitants today. The agri-food industry, with total processed sales worth $£ 2$ billion, plays a vital role in the NI economy. Upland areas, including the Mourne Mountains, offer numerous catchments suitable for the collection and storage of surface water. These gathering grounds are complemented by Lough Neagh (388 km², at about $15 \mathrm{~m} \mathrm{AOD),} \mathrm{the} \mathrm{largest} \mathrm{inland} \mathrm{freshwater} \mathrm{lake} \mathrm{in} \mathrm{the} \mathrm{British} \mathrm{Isles,}$ for public supply throughout the low-lying land (Robins, 1996).

Northern Ireland offers the most compact and diverse range of solid geology, Quaternary deposits and soil types anywhere in Europe. Permian and Triassic sandstones are the most important aquifers in NI. The widespread occurrence of relatively poor aquifers has promoted the development of groundwater in the Quaternary deposits (most notably the Glarryford sand and gravel aquifer). The rivers, lakes, estuaries, seas and groundwater of NI are important natural resources for drinking water, agriculture, industry and fisheries, and for amenity and recreational use. In NI, surface water is the dominant source of public water supply, while groundwater is estimated to provide only $8 \%$ of the total. However, groundwater still has an important role to play because of its contribution to baseflow of surface water, especially in times of low flow. Therefore, both surface water and groundwater are vital to social and economic development throughout the rural community. However, some human activities can threaten water quality. For example, pollutants from point or diffuse sources, especially compounds of nitrogen and phosphorus, resulted in eutrophication in Lough Neagh and other surface water bodies in NI. The results of a number of lake surveys carried out between 1988 and 1994 indicated that some 63\% of NI lakes were either eutrophic or hypertrophic.

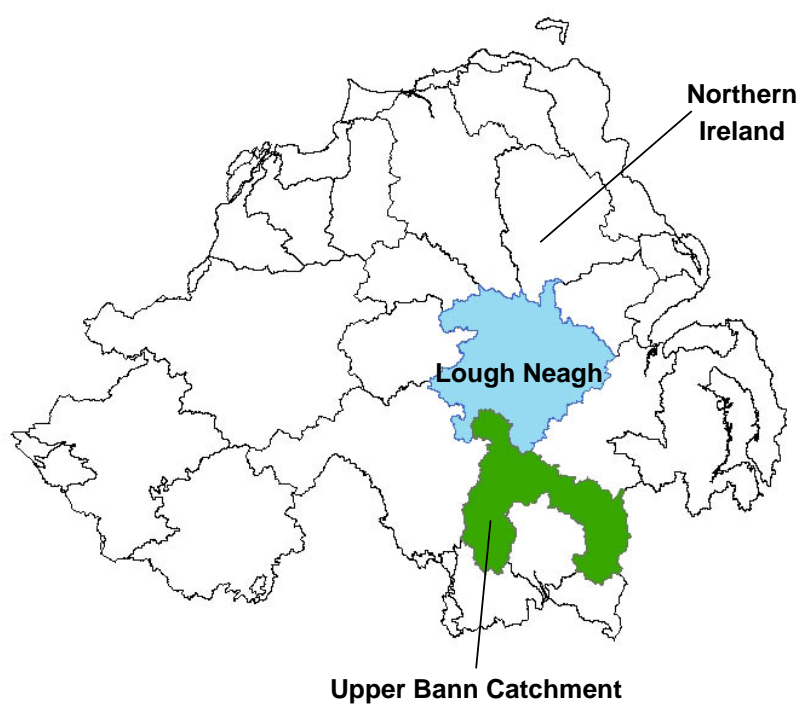

Fig. 1 The location of the Upper Bann catchment in Northern Ireland.

The Upper Bann catchment study area lies in the southeast of NI and the upper River Bann is the largest river supplying Lough Neagh. The study area has a mean annual rainfall of $995 \mathrm{~mm}$ and a mean annual potential evapotranspiration of $516 \mathrm{~mm}$. The topography gently undulates throughout the area, rising from $11 \mathrm{~m}$ at Lough Neagh to a maximum of $672 \mathrm{~m}$ in the Mourne Mountains. The Upper Bann is a complex rural catchment with a wide range of land uses, including fruit growing, livestock farming, arable farming, and urbanization. The dominant soil type is "gleyed" soil that is predominantly comprised of till and clay with 
pockets of peat and alluvial deposits of sand, silt and gravel, and their dominant soil parent materials are drifts and glacial tills derived from basalts, Silurian shales and carboniferous rocks (Cruickshank, 1997). The groundwater table depth rarely exceeds $5 \mathrm{~m}$ in the study area. More details of the catchment are provided by Wang \& Yang (2008).

\section{METHODS}

\section{The DRASTIC approach}

The DRASTIC approach, an index method, provides a numerical ranking composite description of all the major geological and hydrological factors that affect and control groundwater movement into, through, and out across the vertical profiles of an area. Within the intrinsic meaning of groundwater pollution vulnerability, DRASTIC has seven factors:

(1) Depth to water, $D$ - the depth to the aquifer from the ground surface, determines the medium depth through which pollutants travel before reaching the aquifer.

(2) Net recharge, $R$ - the amount of water that penetrates the ground surface and reaches the water table, acts as a principle vehicle for transporting pollutants to the water table through the leaching process.

(3) Aquifer, A - refers to the saturated zone material properties and controls the pollutant permeability and attenuation processes.

(4) Soil media, $S$ - the uppermost weathered portion of the unsaturated zone characterised by significant biological activity, controls the amount of recharge that can infiltrate downward.

(5) Topography, $T$ - the slope of the land surface, dictates the likelihood that runoff will remain on the surface to allow contaminant percolation to the saturated zone.

(6) Impact of vadose zone, $I$ - represents the type of material in the zone above the water table and below the typical soil horizon, which controls the passage and attenuation of the contaminated material to the saturated zone.

(7) Hydraulic conductivity of the aquifer, $C$ - indicates the ability of the aquifer to transmit water, and hence determines the rate of the flow of contaminant material within the groundwater system.

Since the importance of these factors in groundwater pollution processes are different, each factor was assigned a relative weight, ranging from 1 to 5 , determined using a Delphi approach, which quantifies the opinions from single and multiple experts. The most significant factor has a weight of 5 and the least significant one has a weight of 1 .

The involvement of multi-sphere factors, i.e. the hydrosphere, atmosphere and geosphere, makes the ADGWP vulnerability assessment an inherently geographical activity requiring the handling of multiple forms of spatial data. With its advantages for spatial data management, analysis and visualisation, ArcGIS 9.0 was adopted for the data preparation, and the mathematic calculation of the raster data layers in the DRASTIC method. The definition of the DRASTIC index in GIS was adapted (equation 1) from the original definition of Aller et al. (1987):

$$
\mathrm{DVI}_{i}=D_{i w} D_{i r}+R_{i w} R_{i r}+A_{i w} A_{i r}+S_{i w} S_{i r}+T_{i w} T_{i r}+I_{i w} I_{i r}+C_{i w} C_{i r}
$$

where DVI represents the DRASTIC vulnerability index; the subscript $i$ is the $i$ th cell in the GIS raster data structure; $D, R, A, S, T, I$ and $C$ are the seven factors in DRASTIC; the subscripts $r$ and $w$ are the numerical ratings (to be calculated) and weightings of the seven factors, respectively.

The assumptions of DRASTIC include:

(1) the contaminant is introduced at the ground surface;

(2) the contaminant is flushed into the ground water by precipitation;

(3) the contaminant is soluble; and

(4) the area assessed using DRASTIC is $0.4 \mathrm{~km}^{2}$ or larger (Aller et al., 1987).

In ADGWP, the soluble pollutants from the agricultural land use percolate into 
groundwater with net recharge water. The weights of $D, R, A, S, T, I$ and $C$ in equation (1) are $5,4,3,2,1,5$ and 3, respectively, for general pollutant, while they are 5, 4, 3, 5, 3, 4 and 2 for pesticide groundwater pollution vulnerability calculation. According to the DRASTIC manual, the numerical rating rules, defined in DRASTIC using the Delphi approach, cannot be changed. Within DRASTIC, each factor has its ranges or significant media types for assigning its rating value that represents its relative significance in the impact on groundwater pollution potential. The preparation and analysis of data and the implementation of the DRASTIC method were performed using ArcGIS.

\section{Parameter maps in GIS}

Prior to application of the DRASTIC model, a GIS database was set up. Borehole, drift and solid geology data were provided by the Geological Survey of Northern Ireland (GSNI); meteorological data were from the British Atmospheric Data Centre (BADC); the land cover data were provided by the Centre for Ecology and Hydrology (CEH); the soil data were acquired from the Department of Agriculture and Rural Development (DARD) of Northern Ireland; and the DEM data were obtained from the Environmental Heritage Service (EHS). In order to facilitate the application of DRASTIC, all the DRASTIC factor data were converted into a raster data format in the ArcGIS platform with a resolution of $50 \mathrm{~m} \times 50 \mathrm{~m}$. The rating of the seven factors in DRASTIC was based on the standards set in the DRASTIC manual.

Depth to water

The data for "depth to water" in the study area were obtained from 660 borehole logs containing the first water strike information. These point data were interpolated to a continuous raster layer representing the water table surface. A deeper water table implies less chance for contamination to occur because of the longer transport time, greater opportunity for chemical reaction and the occurrence of pollutant attenuation (Aller et al., 1987). In the study area, the depth of water table below ground is shallow, with an average value of $2.5 \mathrm{~m}$, and three rating values were calculated, i.e. $7(4.6-9.1 \mathrm{~m}), 9(1.5-4.6 \mathrm{~m})$ and $10(0-1.5 \mathrm{~m})$. In DRASTIC, the higher ratings imply greater groundwater pollution potential and vice versa.

Net recharge

Net recharge in the DRASTIC method is the amount of precipitation minus surface runoff and evapotranspiration. The mean precipitation and evapotranspiration of 10 years from 1990 to 2000 were interpolated from the meteorological data. Surface runoff data was calculated adopting the US Natural Resources Conservation Service (NRCS) curve number (CN) method (NRCS, 2004). Both land cover and soil properties influence the process of runoff generation. Land covers in the study area were reclassified into brush, woods, row crop, pasture, fallow, water and urban area, according to the NRCS CN method. Since this study was focusing on the soluble pollutants from diffuse agricultural sources, the urban areas were regarded as impervious surface. Based on the soil properties, soil in the study area was classified into four groups (A, B, C and D) with A having low runoff potential and D having high runoff potential. The curve number in each cell of the area was determined using the land use and soil re-classification data. In this method, the curve number of the impervious land and water body were assigned a value of 98. The runoff value in each cell of the study area was calculated using:

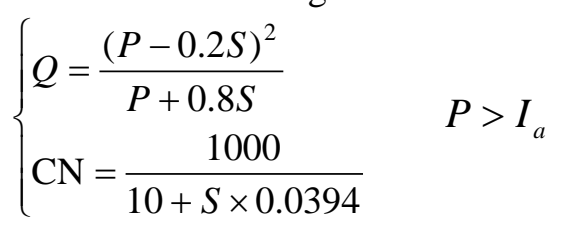

where $Q$ is the depth of runoff, $P$ the depth of rainfall, and $I_{a}$ the initial abstraction, all in $\mathrm{mm}$. $I_{a}$ consists mainly of interception, infiltration during the early parts of storm and surface depression storage. $S$ is the maximum potential retention in $\mathrm{mm}$; the relationship between $I_{a}$ and $S$ is expressed as $I_{a}=0.2 S$ (NRCS, 2004). CN is the curve number showing graphically the relationship between rainfall and runoff. 
With the average value of $147.3 \mathrm{~mm}$, the net recharge GIS raster layer for the area was classified into five ranges and assigned rating values of $1(0-50.8 \mathrm{~mm}), 3(50.8-101.6 \mathrm{~mm}), 6$ (101.6-177.8 mm), 8 (177.8-254 mm) and 9 (>254 mm). Higher net recharge rating values mean higher recharge rates and higher groundwater pollution potential.

\section{Aquifer media}

Consolidated and unconsolidated rock may serve as an aquifer. In general, the larger the grain size or the more fractures and openings within the aquifer, the higher the permeability and the lower the attenuation capacity the aquifer media have. Aquifer media information for the study area was obtained from drift geology maps and previous hydrogeological investigations. The study area is covered in a thick layer of glacial drift (5-20 m) with very few outcrops of bedrock left exposed. Overlying these are recent peat and alluvial deposits; the latter may vary from gravels to laminated clays (Wang \& Yang, 2008). Aquifer media in the study area consist of glacial till, peat, sand and gravel, alluvium (sand and silt) and outcrop rock in exposure. The glacial till is unconsolidated to semi-consolidated mixtures of gravel, sand, silt and clay-size particles that are poorly sorted and stratified. The low permeability glacial till was assigned a rating value 5 . The peat, which consists of undecomposed to partially decomposed plant material that is fresh enough to be identified and is relatively permeable but with a high contaminant attenuation, was assigned a rating value 4 . Sand and gravel were given a rating value 8 because of their high permeability. Alluvium, mainly finer-grained and "dirtier" sands, was given a rating value 6 . Information regarding the outcropping rocks was obtained from the solid geology map. In the study area, the outcrop rocks include basalt (dolerite), igneous rock (felsite, granite, granodiorite), shale (mudstone) and sandstone, which were assigned rating values of 9, 3, 2 and 6, respectively, according to the definitions in DRASTIC. A higher aquifer media rating value means higher permeability, lower attenuation capacity of the aquifer media and higher groundwater pollution potential.

Soil media

Soil media information was gathered from the Northern Ireland soils database (DARD, 1997). In general, the less the clay shrinks and swells and the smaller the grain size, the less the pollution potential. Based on the sand, silt and clay content of each soil type, quantified by Cruickshank (1997), soils in the study area were re-classified using the British Soil Classification Standard BS3882. The quantity of organic material present in the soil may also be an important factor in the attenuation of pesticides. Table 1 shows the soil types, their composition, soil media re-classification and each soil type rating for the study area. Urban areas were regarded as impervious surface by assigning rating value 1 . Water bodies, such as lakes, wet land and ponds, were treated as thin or absent soil by assigning a rating value of 10 - the highest groundwater pollution potential.

Table 1 Soils properties and their DRASTIC rating values (modified from Wang \& Yang, 2008).

\begin{tabular}{ccccc}
\hline $\begin{array}{c}\text { Soil media } \\
\text { classification }\end{array}$ & Sand (\%) & Silt (\%) & Clay (\%) & Soil rating \\
\hline Loam & $41.7 \sim 47.8$ & $34.6 \sim 39.7$ & $15.7 \sim 23.6$ & 5 \\
Sandy loam & $46.3 \sim 61.65$ & $22.6 \sim 38.8$ & $12.6 \sim 15.7$ & 6 \\
Loam & $41.7 \sim 47.8$ & $34.6 \sim 39.7$ & $15.7 \sim 23.6$ & 5 \\
Sandy loam & $63.4 \sim 80.9$ & $15.6 \sim 25.7$ & $2.8 \sim 10.3$ & 6 \\
Sandy loam & $49.8 \sim 65.8$ & $20.4 \sim 26.4$ & $13.8 \sim 23.8$ & 6 \\
Loam & $29.7 \sim 50.8$ & $38.6 \sim 42.4$ & $14.6 \sim 27.9$ & 5 \\
Loam & $29.7 \sim 50.8$ & $38.6 \sim 42.4$ & $14.6 \sim 27.9$ & 5 \\
Sandy clay loam & $45.4 \sim 48.9$ & $24.2 \sim 26.6$ & $26.9 \sim 28.8$ & 4 \\
Sandy loam & $61.5 \sim 68.3$ & $18.8 \sim 22.5$ & $10.8 \sim 15.5$ & 6 \\
Loam & $34.5 \sim 38.9$ & $38.8 \sim 42.1$ & $20.5 \sim 25.7$ & 5 \\
Sandy loam & $61.2 \sim 67.5$ & $17.4 \sim 20.1$ & $12.5 \sim 19.6$ & 6
\end{tabular}




\begin{tabular}{ccccc} 
Loam & $38.3 \sim 40.5$ & $41.2 \sim 44.1$ & $17.6 \sim 18.3$ & 5 \\
Clay loam & $27.2 \sim 39.2$ & $33.1 \sim 35.1$ & $27.5 \sim 37.5$ & 3 \\
Clay loam & $34.7 \sim 52.7$ & $28.1 \sim 30.5$ & $19.2 \sim 35.2$ & 3 \\
Loam & $35.8 \sim 51.5$ & $31.9 \sim 43.1$ & $16.2 \sim 21.1$ & 5 \\
Loam & $41.0 \sim 55.7$ & $25.4 \sim 36.7$ & $18.9 \sim 22.9$ & 5 \\
Clay loam & $25.2 \sim 32.7$ & $43.4 \sim 43.8$ & $23.4 \sim 31.4$ & 3 \\
Silt Loam & $7.5 \sim 21.9$ & $70.0 \sim 77.6$ & $0.5 \sim 22.5$ & 4 \\
Clay loam & $25.2 \sim 32.8$ & $43.4 \sim 43.8$ & $23.4 \sim 31.4$ & 3 \\
Loamy sand & 83.3 & 13 & 3.8 & 9 \\
Sandy loam & $52.7 \sim 61.5$ & $36.0 \sim 36.4$ & $2.5 \sim 10.9$ & 6 \\
Sandy loam & $52.7 \sim 61.5$ & $36.0 \sim 36.5$ & $2.5 \sim 10.10$ & 6 \\
\hline
\end{tabular}

Topography

Slopes, which provide a greater opportunity for pollutants to infiltrate, will be associated with higher groundwater pollution potential. Topography also controls the gradient and direction of flow. Typically, steeper slopes signify higher groundwater velocity. Slope in the study area was derived from DEM data in ArcGIS, and then was divided into ranges and assigned ratings from 1 to 10 according to the DRASTIC rating standard. It is worth noting that the ranges of "percent slope" described in the DRASTIC model are recommended to be converted to degree slope when applying DRASTIC in GIS. Steep areas were assigned low rating values because they increase the runoff washing out contaminants, whilst flat areas, slow down the runoff and allow more time for percolation, were given high rating values.

Impact of vadose zone media

The media type determines the process of biodegradation, neutralisation, mechanical filtration, chemical reaction, volatilisation and dispersion in the vadose zone. Vadose zone media identification and classification were based on the soil map, drift geology map, borehole data and water table depth information. Rocks (shale, basalt, igneous, shale and sandstone) and drifts (glacial till and gravel) were found in the study area. The rating for the thin gravel was assigned 10 - the highest pollution potential. The components of the glacial tills and their drainage properties vary greatly. With the soil database and the detailed soil properties information, the glacial tills were re-grouped according to their sand contents (787\%). Sandy till is "sand and gravel with significant silt and clay" (definition in DRASTIC) with rating value 6; whilst a dense, un-fractured, clayey till (silt/clay) was assigned rating value 3. Other types of glacial till were respectively assigned the rating values between 3 and 6 , on the basis of their sand contents. Vadose zone media ratings reflect the grain size, sorting, homogeneity and amount of fine material. Higher rating value means higher groundwater pollution potential.

Aquifer hydraulic conductivity

The values of aquifer hydraulic conductivity $(K)$ were estimated based on the $K$ ranges provided in the DRASTIC method and validated using values from the literature and pumping tests in nearby areas. The $K$ values in the area were assigned rating values of $1(0.04-4.1$ $\mathrm{m} / \mathrm{d}), 2$ (4.1-12.2 m/d), 6 (28.5-41 m/d), 8 (41-82 m/d), and 10 (>82 m/d). Higher $K$ ratings imply the higher aquifer permeability and higher groundwater pollution potential.

\section{RESULTS}

The DRASTIC factors

Although the DRASTIC index values (see details in Fig. 9 from Wang \& Yang, 2008) represent the overall groundwater vulnerability, the result of each factor is also useful in understanding the groundwater pollution pathways in a study area. In the "depth to water" rating layer, comparatively high groundwater pollution potential cells with rating values of 9 and 10 cover $98 \%$ of the study catchment. Cells with value 7 are located in the low-lying area 
to the middle and northwest of the study catchment. High net recharge ratings of 8 (13\% of the total study area) and 9 (21\%) can be found in the mountain areas, whereas low net recharge ratings 1 (31\%) and 3 (17\%) are located in low-lying areas. The undulating drumlin areas have a moderate net recharge rating, i.e. $6(18 \%)$. In the aquifer rating result, most parts of the area has a rating value 5 (78\%) standing for glacial till media for unconfined aquifer. Against the background of rating 5, the strips of alluvium, sand and silt developed along streams and rivers have comparatively higher groundwater pollution potential with the rating 6 (11\%). Outcrops in mountain areas with rating $2(1 \%)$ and $3(3 \%)$ have low groundwater pollution potential. With the dominant soil types of "loam" - rating 5 (52\%), “clay loam” - 3 (16\%) and "sandy loam" - 6 (15\%), the soil media rating values gradually decrease from mountain areas to low-lying areas, except in a small area immediately south of Lough Neagh that is covered by peat and has a higher vulnerability than the basalt and till around it. In the topography rating layer, the steep slope cells with the rating values of $1(5 \%)$ and $3(10 \%)$ are located in the mountain areas to the southeast, southwest and east of the study area. In contrast, the low-lying area to the northwest of the study area has high ratings of 9 (33\%) and 10 (22\%). In addition, the undulating area of the rest of the study has mixed values of $1,3,5$ (30\%), 9 and 10. The vadose zone media with the rating value 6 (15\%) - "alluvium strata" developing along streams or rivers on the background of rating 4 (72\%) - "till" - form distinct strips with comparatively high groundwater pollution potential. High rating values 8 (1\%), $9(1 \%)$ and $10(2 \%)$ can be found in mountain areas. In the $K$ rating layer, most parts of the area have comparatively low aquifer permeability with rating values of $1(81 \%)$ and 2 (6\%), while cells with rating value 8 (8\%) form obvious alluvium strips along streams or rivers.

\section{Groundwater pollution vulnerability}

The groundwater vulnerability for general pollutants and also the groundwater pesticide vulnerability were calculated using equation (1). For general pollutants, ten vulnerability ranks were identified in the study area. Fig. 2 shows "high" (4.5\% of total area) and "moderate" (25.5\%) vulnerability zones in the mountain areas to the southeast (Mourne Mountains), east (Slieve Croob) and southwest (source of River Cusher) due to high rainfall, net recharge and soil permeability. "Low" (73.8\%) vulnerability zones can be found in the middle and northwest of the study area where the covering soil has low permeability. Because of the high permeability of alluvium, sand and gravel in the riverbeds, strips along streams/rivers have comparatively higher vulnerability ranks than their backgrounds. The groundwater pesticide vulnerability map (Fig. 3) has a distribution of rankings similar to Fig. 2. However, the "high" (4.7\%) and "moderate" (50.7\%) vulnerability zones in Fig. 3 have higher proportions than that of Fig. 2. 


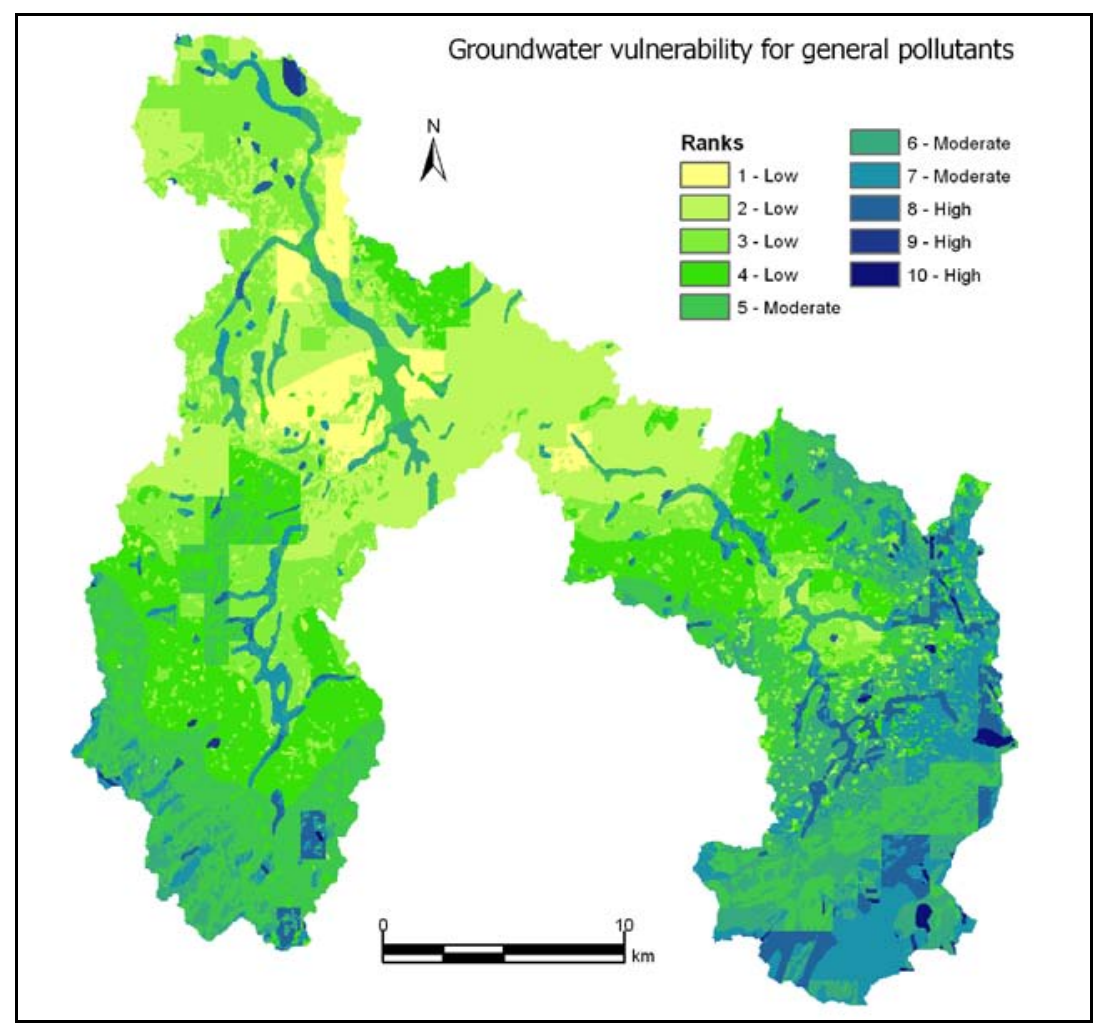

Fig. 2 Groundwater vulnerability for general pollutants in the Upper Bann catchment.

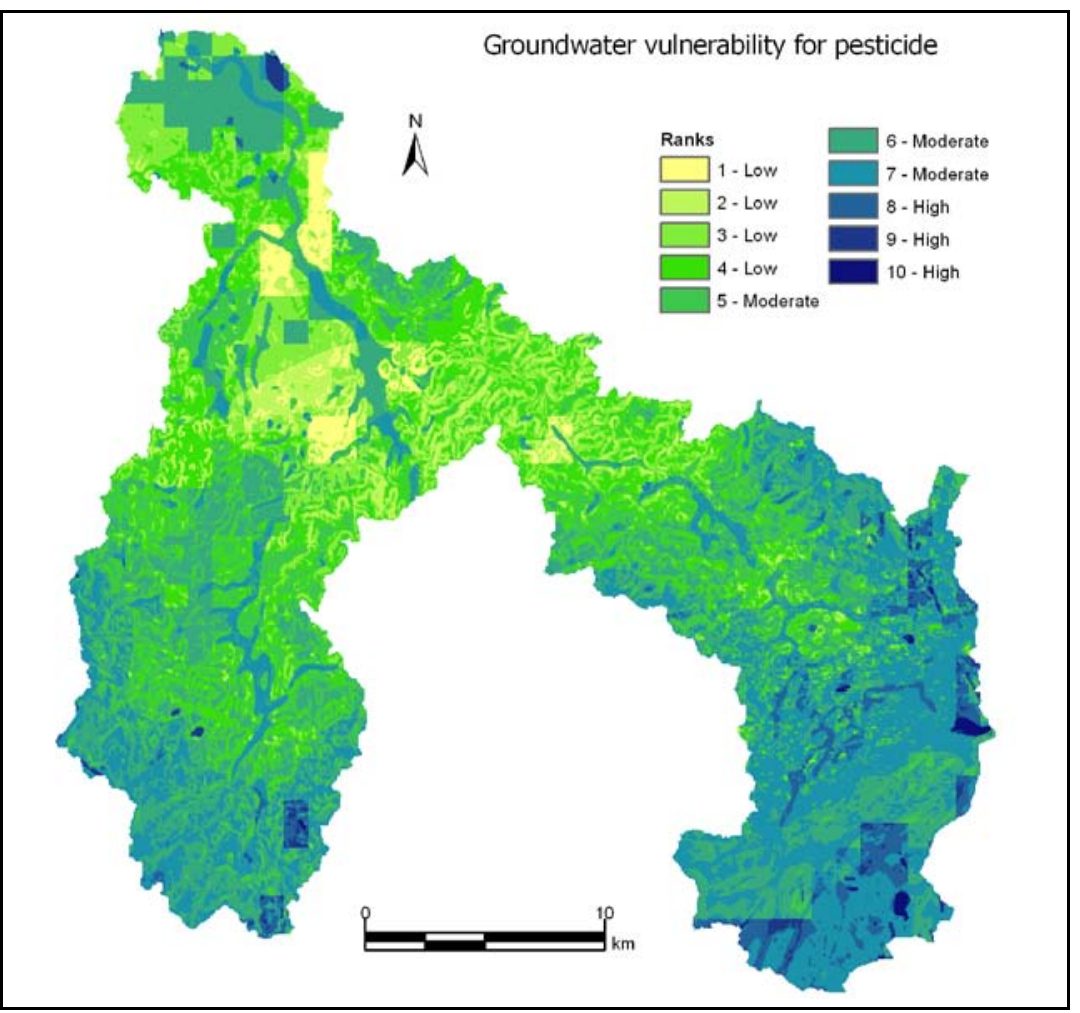

Fig. 3 Groundwater pesticide vulnerability in the Upper Bann catchment.

Generally, the high ADGWP risk is associated with arable land having higher fertilizer or pesticide application rates than other land uses. Thus, the more vulnerable zones in mountain areas with little arable land use may have low ADGWP risk. However, some of the less 
vulnerable areas in the low-lying part of the study area have a higher ADGWP risk mainly due to the higher density of arable land use areas. The land use layer was overlain with the groundwater water pollution vulnerability map, in order to reflect the ADGWP risk by considering pollution sources. Taking nitrate as an example, the result in Fig. 4 is in line with the trend of the groundwater nitrate concentration data from four locations in the Northern Ireland monitoring network in the study area.

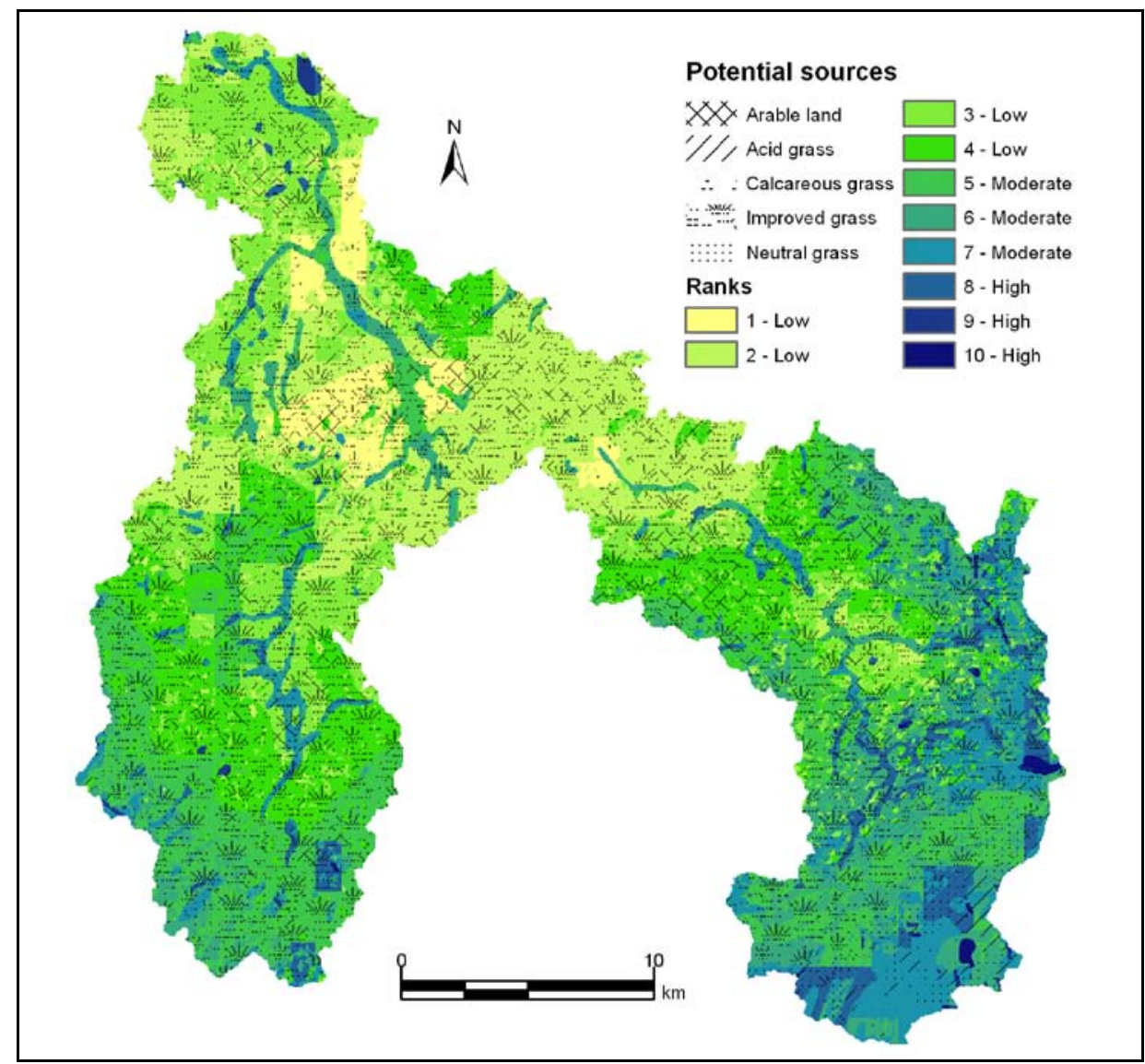

Fig. 4 Overlaying the land-use map on the groundwater vulnerability map in the Upper Bann catchment.

\section{DISCUSSION}

DRASTIC is helpful for tackling ADGWP at the catchment scale in the implementation of the EU Water Framework Directive (WFD). The EU WFD introduces an innovative, integrated and holistic approach to the protection and management of water resources. Agricultural diffuse water pollution has been identified as a major threat to achieving the demands of the EU WFD (Ferrier et al., 2004; Torrecilla et al., 2005). So far, the answer to the question: "what technical measures will actually be used or developed in the implementation of the EU WFD?” is still largely unknown (UK EA, 2005). By considering seven factors in the pathway of soluble pollutants reaching groundwater from the ground surface, the DRASTIC results are useful for guiding prevention activities for ADGWP by delineating groundwater pollution vulnerability zones. In addition, the DRASTIC model can be easily transferred to other catchments by following the rules of parameter ranking defined in the DRASTIC manual.

Although DRASTIC is an index method with the subjective weighting and the numerical value assignation for various factors, the selected factors and their subjective weights can reflect the key mechanism of processes in the groundwater pollution pathway well. Thus, DRASTIC has been used worldwide for groundwater vulnerability assessment at both large 
and small scales (Worrall \& Kolpin, 2004; Babiker et al., 2005; Hamza et al., 2007). Nevertheless, DRASTIC has drawbacks in the prevention of ADGWP at the catchment scale. For example, DRASTIC reflects pathway vulnerability in ADGWP, but both pathway vulnerability and pollution sources are needed for actual ADGWP management. Although the overlaying of the DRASTIC index and the land use maps in Fig. 4 provides a better result than Fig. 2, judgement of the exact target zones for ADGWP prevention is still not easy. Therefore, it is necessary to develop a more reliable ADGWP risk assessment method that is able to explicitly point out high ADGWP zones by mathematically introducing the concept of the risk of ADGWP and pollutant movement with runoff into DRASTIC.

With the advantages of spatial data management, analysis and visualisation, GIS can greatly facilitate the application of the DRASTIC model by improving the efficiency of data preparation and index calculation in raster data format.

\section{CONCLUSIONS}

The vulnerability maps of groundwater pollution for both general pollutants and pesticide in the Upper Bann catchment, Northern Ireland, were generated using the DRASTIC method in an ArcGIS environment. These results can guide the ADGWP prevention activities at the catchment scale and hence are helpful for the implementation of the EU WFD in handling the ADGWP. However, the DRASTIC result is the pathway vulnerability of groundwater pollution instead of the groundwater pollution risk.

Acknowledgements The authors wish to acknowledge the assistance of GSNI, EHS, CEH UK, BADC and DARD for providing the relevant data. The work was also supported by the MOE Chang-Jiang Scholars Programme (China) and the Ministry of Science \& Technology 863 Project (2007AA06Z343).

\section{REFERENCES}

Aller, L., Bennett, T., Lehr, J.H., Petty, R.J. \& Hackett, G. (1987) DRASTIC: A standardised system for evaluating groundwater pollution potential using hydrogeologic settings. EPA/600/2-87/035, US Environment Protection Agency, Ada, Oklahoma, USA.

Babiker, I. S., Mohamed, M. A. A., Hiyama, T. \& Kato, K. (2005) A GIS-based DRASTIC model for assessing aquifer vulnerability in Kakamigahara Heights, Gifu Prefecture, central Japan. Sci. Total Environ. 345, 127-140.

Barbash, J. E. \& Resek, E. A. (1996) Pesticides in Ground Water: distribution, trends, and governing factors. Ann Arbor Press.

Bekesi, G. \& McConchie, J. (2002) The use of aquifer-media characteristics Manawatu region, New Zealand. Hydrogeol. J. 10, 322-331.

Cruickshank, J. G. (1997) Soil and Environment, Northern Ireland. The Queen’s University of Belfast, Belfast, UK.

Daly, D., Dassargues, A., Drew, D., Dunne, S., Goldscheider, N., Neale, S., Popescu, I. \& Zwahlen, F. (2002) Main concepts of the "European approach" to karst-groundwatervulnerability assessment and mapping. Hydrogeol. J. 10, 340-345.

DARD (Department of Agriculture and Rural Development) (1997) Soils Database of Northern Ireland. Department of Agriculture and Rural Development, Northern Ireland.

Defra [spell out in full] (2002a) The Government's Strategic Review of diffuse water pollution from agriculture in England: Agriculture and water - A diffuse pollution review. Publication details?

Dixon, B., Scott, H. D., Dixon, J. C. \& Steele, K. F. (2002) Prediction of aquifer vulnerability to pesticides using fuzzy rule-based models at the regional scale. Phys. Geogr. 23, 130-153. 
Ferrier, B., D’Arcy, B., MacDonald, J. \& Aitken, M. (2004) Diffuse Pollution - What is the nature of the problem? The Water Framework Directive: Integrating Approaches to Diffuse Pollution, SOAS, London.

Gemitzi, A., Petalas, C., Tsihrintzis, V. A. \& Pisinaras, V. (2006) Assessment of groundwater vulnerability to pollution: a combination of GIS, fuzzy logic and decision making techniques. Environ. Geol. 49(3), 653-673.

Giupponi, C. \& Vladimirova, I. (2006) Ag-PIE: A GIS-based screening model for assessing agricultural pressures and impacts on water quality on a European scale. Sci. Total Environ. 359, 57-75.

Gogu, R. C. \& Dassargues, A. (2000) Current trends and future challenges in groundwater vulnerability assessment using overlay and index methods. Environ. Geol. 39, 549559.

Gogu, R. C., Hallet, V. \& Dassargues, A. (2003) Comparison of aquifer vulnerability assessment techniques. Application to the Néblon River basin (Belgium). Environ. Geol. 44, 881-892.

Hamza, M. H., Addeda, R. A., Abdeljaoueda, S. \& Mammou, B. A. (2007) A GIS-based DRASTIC vulnerability and net recharge reassessment in an aquifer of a semi-arid region (Metline-Ras Jebel-Raf Raf aquifer, northern Tunisia). J. Environ. Manag. 64(1), 12-19.

Jordan, C. \& Smith, R. V. (2005) Methods to predict the agricultural contribution to catchment nitrate loads: designation of nitrate vulnerable zones in Northern Ireland. $J$. Hydrol. 304, 316-329.

Koo, B. K. \& O’Connell, P. E. (2006) An integrated modelling and multicriteria analysis approach to managing nitrate diffuse pollution: 1. Framework and methodology. Sci. Total Environ. 359, 1-16.

Matson, P. A., Parton, W. J., Power, A. G. \& Swift, M. J. (1997) Agricultural intensification and ecosystem properties. Science 277, 504-509.

NRCS (Natural Resources Conservation Service) (2004) Part 630: Hydrology, National Engineering Handbook. US Department of Agriculture.

Palmer, R. C. \& Lewis, M. A. (1998) Assessment of groundwater vulnerability in England and Wales. In: Groundwater Pollution, Aquifer Recharge and Vulnerability (ed. by N. S. Robins), 191-198. Geological Society, London, Special Publication 130.

Palmer, R. C., Holman, I. P., Robins, N. S. \& Lewis, M. A. (1995) Guide to groundwater vulnerability mapping in England and Wales. National Rivers Authority, Bristol, UK.

Pretty, J. N., Brett, C., Gee, D., Hine, R. E., Mason, C. F., Morison, J. I. L., Raven, H., Rayment, M. D. \& Van der Bijl, G. (2000) An assessment of the total external costs of UK agriculture. Agric. Systems 65(2), 113-136.

Rademaher, J. J., Young, T. B. \& Kanarek, M. S. (1992) Gastric cancer mortality and nitrate levels in Wisconsin drinking water. Arch. Environ. Health 47(4), 292-294.

Robins, N. S. (1996) Hydrogeology in Northern Ireland. British Geological Survey: HMSO, UK.

Rupert, M. G. (2001) Calibration of the DRASTIC ground water. vulnerability mapping method. Ground Water 39(4), 625-630.

Thapinta, A. \& Hudak, P. F. (2003) Use of geographic information systems for assessing groundwater pollution potential by pesticides in Central Thailand. Environ. Int. 29, 87-93.

Torrecilla, N. J., Galve, J. P., Zaera, L. G., Retamar, J. F. Álvarez, A. N. A. (2005) Nutrient sources and dynamics in a Mediterranean fluvial regime (Ebro River, NE Spain) and their implications for water management. J. Hydrol. 304, 166-182.

UK EA [spell out in full] (2005) The Relationship between the land use planning system and the Water Framework Directive. UK.

USDA (US Department of Agriculture) (1991) Nitrate occurrence in U.S. waters (and related questions). USDA, Washington, DC.

Vrba, J. \& Zoporozec, A. (1994) Guidebook on mapping groundwater vulnerability. IAH International Contribution for Hydrogeology, vol. 16. Hannover: Heise. 
Wang, L. \& Yang, Y. S. (2008) An approach for catchment-scale groundwater nitrate risk assessment from diffuse agricultural sources: a case study in the Upper Bann, Northern Ireland. Hydrol. Processes 22, 4274-4286.

Worrall, F. \& Besien T. (2005) The vulnerability of groundwater to pesticide contamination estimated directly from observations of presence or absence in wells. Journal of Hydrology 303, 92-107.

Worrall, F. \& Kolpin, D. W. (2004) Aquifer vulnerability to pesticide pollution - combining soil, land-use and aquifer properties with molecular descriptors. J. Hydrol. 293, 191204.

Yang, Y. S. \& Wang, L. (2010) A Review of Modelling Tools for Implementation of the EU Water Framework Directive in Handling Diffuse Water Pollution. Water Resour Manage (in press).

Yang, C. Y., Wu, D. C. \& Chang, C. C. (2007) Nitrate in drinking water and risk of death from colon cancer in Taiwan. Environ. Int. 33(5), 649-653. 